\title{
Mapping Police Services in the Democratic Republic of Congo
}

\author{
Thierry Nlandu Mayamba*
}

\begin{abstract}
This article examines the roles, responsibilities and interactions between the various formal and informal institutions and stakeholders involved in the management of police services in the DRC. It identifies informal networks that influence decision-making processes and policy implementation. It also identifies gaps and contradictions in the existing legal framework and uses a multidimensional governance approach to understand the complexity of the security sector, the overlap and the interconnectedness between the relevant actors. The study also provides an analysis of interactions between the Congolese population and national and international actors, and the recent efforts to secure police reform. It concludes that the poor coordination between the various actors and institutions involved in the management of security services in the DRC creates a dysfunctional structure characterised by a culture of impunity, with no regard for senior civil servants in charge of coordination.
\end{abstract}

\begin{abstract}
1 Introduction
Since the 2006 elections, the Democratic Republic of Congo (DRG) has been trying to establish democratic institutions. Central to this is the security and justice sector, with the police at its heart. This article maps out the Congolese state and non-state actors and international stakeholders involved in providing and managing police services, with particular emphasis on the informal networks influencing decision-making processes and policy implementation. It also analyses the interactions between the police, national and local actors, and citizens.
\end{abstract}

The task is challenging, due to the multiplicity of security sector actors and the interconnectedness of services. Nevertheless, the article provides information on the history and organisational structure of these services; the different actors and networks involved in managing them; and the impact on service quality, using a case study of the Bas-Congo Province for illustration.

\section{Historical and legal evolution of Congolese police services \\ 2.1 Evolution of the police force}

To understand how the police are managed in the DRC, it is important to consider the country's historical and institutional contexts.
The roles, responsibilities and interactions between various institutions and actors linked with the police at central, provincial and local levels are examined, as well as the legal texts pertaining to the country's security. The article highlights horizontal and vertical accountability mechanisms within the existing legal framework, and the legal gaps and contradictions that may explain overlapping mandates. The reference to legal texts demonstrates that the key resources available to Congolese actors rest on the existing legal framework and its loopholes, which they know how to exploit for political gain. Crucially, they also rest on the powerful informal networks.

The evolution of the legal framework from 1959 to 2006 explains in part the structure of the Police Nationale Congolaise (National Congolese Police, PNC hereafter). The history points to the overlap between the military and law enforcement functions, which has prevailed since Independence. The PNG has constantly fought to transform itself from an institution serving one man and his followers into a truly public service.

From 1885 to 1908, under the control of King Leopold II of Belgium, the Etat Indépendent Congolais (EIC, Independent Congolese State) did not have a police force. When the country became

IDS Bulletin Volume 43 Number 4 July 2012 @ 2012 The Author. IDS Bulletin @ 2012 Institute of Development Studies Published by Blackwell Publishing Ltd, 9600 Garsington Road, Oxford OX4 2DQ, UK and 350 Main Street, Malden, MA 02148, USA 
a Belgian colony in 1908, it acquired a force publique (public force) responsible for both the army and the police. Its key role was to oversee the establishment and the protection of the colony.

After the Second World War, the colonial government sent representatives of the force publique and soldiers to help territorial administrators maintain law and order in new cities and rural areas under the control of customary centres of power, which were becoming increasingly more populated. This process was important in the establishment of the police in the Congo for two reasons: firstly, it marked the beginning of a territorial law enforcement service, which paved the way for provincial governors to set up urban police forces. It also marked the beginning of a professional trained police force at officer level and for natives only (all positions of leadership and command were reserved exclusively for white people).

The bloody repression of the events of 4 January $1959^{1}$ prompted colonial authorities to create the gendarmerie, made up of former soldiers trained as police officers. After Independence in 1960, there were three law enforcement structures carrying out police interventions: the force publique, the police urbaine (urban police) and the newly formed gendarmerie (Ebenga and Nlandu 2005). They played a destabilising role in a chaotic postIndependence period marked by many riots, secessions and armed rebellions leading up to the military coup on 24 November 1965, which brought General Mobutu to power. The former urban police forces became the territorial police forces, used as puppets by power-hungry politicians and responsible for the country's Balkanisation.

In July 1966, Mobutu decided to unite all police forces within one force - the PNC - created by presidential decree $n^{\circ} 66 / 423$. This reform established a police force with one central point of command and management, and the equal distribution of personnel across the provincial police, separate from the gendarmerie. The PNG was mandated to maintain public order, ensure public safety and salubriousness, and carry out surveillance. ${ }^{2}$ In practice however, most police services had the political mission of protecting and ensuring the survival of Mobutu's regime.

Reunited after a long period of tribal wars, the country became the Republic of Zaïre in 1971 and integrated all its forces into one single force capable of quashing any hostility against the regime. The gendarmerie nationale was created by presidential decree $n^{\circ} 72 / 31$ on 31 July 1972 , following the dissolution of the national police force and the post-Independence gendarmerie, both rendered inefficient due to their constant rivalry. The gendarmerie nationale became an integral part of the army and therefore a militarised force. ${ }^{3}$

The impoverished ${ }^{4}$ gendarmerie nationale rapidly became an instrument of oppression. It was replaced by the garde civile (civil guard), created by decree-law n ${ }^{\circ} 84-036$ on 28 August 1984, modified and completed by decree-law 002 on 14 March 1992, ${ }^{5}$ with the same mission as the gendarmerie nationale, but better equipped and trained militarily. The garde civile was a kind of anti-riot police force modelled on the German federal police.

During the so-called 'war of liberation', which began in 1997, the l'Alliance des Forces

Démocratiques (Allied Democratic Forces, AFDL) created a new police force (separate from the forces still engaged in combat). Most agents in this new force were recruited hastily and lacked any appropriate training. The fall of Kinshasa on 17 May 1997 saw the formal establishment of this new structure, which called upon many experienced ex-military officers and former members of the gendarmerie and garde civile to join its ranks. The new police force was not enshrined in law until the enactment of legal decrees $\mathrm{n}^{\circ} 002 / 2002$ dated 26 January 2002 (establishing the organisation and operations of the PNC) and $\mathrm{n}^{\circ} 042 / 2002$ (instigating the visibility of ranks). Articles 182-186 of the 2006 Congolese Constitution (Democratic Republic of Congo 2006) also elaborate on the PNC's functions and mandate.

\subsection{A cycle of failed reforms?}

The set of reforms mentioned above create a heterogeneous force made up of former officers from various backgrounds: the force publique, including retired officers; the colonial urban police force; the former national police force; the national gendarmerie; ex-militias; ex-military personnel; the widows and orphans of deceased police officers and both educated and illiterate volunteers (CSRP Working Group 2009). These ex-combatants are integrated into the police without any military or police training. 
Further, the militarisation of the police is sanctioned by the Constitution (Article 81), as higher ranking officers are nominated on the advice of the Superior Defence Council, which is part of the army. Police officers are subject to trial in martial courts of law (Article 156), composed of army officials, magistrates and nonmagistrates.

Throughout the post-Independence period, a number of ill-conceived and politicised attempts were made to develop a community police service through the establishment of militia groups such as the Corps des Volontaires de la République (Republican Volunteer Corps, or CVR), the Forces d'Auto-défense Populaire (People's Self-defence Forces, or FAP) and the Unités de Défense Locale (Local Defence Units, or UDL). Common across these initiatives was their inability to rid the police of its military and oppressive nature.

\section{Stakeholders $^{6}$}

Both the legislative and executive branches of government have a bearing on the way the police are managed, with the executive often superseding the legislative branch when it comes to security issues. A number of non-state actors have also emerged, including civil society organisations and networks supported by the international community. Whether or not they become credible counter-powers remains to be seen.

\subsection{The executive}

The executive branch of government comprises a variety of stakeholders involved in managing police services. These include the President, the Minister of the Interior, the police Inspector General, the PNC, l'Agence Nationale de Renseignements (the National Intelligence Agency, or ANR), the Direction Générale des Migration (General Directorate for Migration, or DGM), the police judiciaire des parquets (police force in charge of criminal investigations), and the Comité pour le Suivi de la Réforme de la Police (Committee for the Monitoring of Police Reform, or CSRP).

\subsection{The President of the Republic: institutional and informal resources}

According to Article 83 of the Constitution, the President is the Commander in Chief of the Armed Forces. Articles 81.2 and 81.3 specify that 'the President nominates, dismisses or revokes generals and high-ranking officers within the armed forces and the national police force, without prejudice to any other provisions of the Constitution'.

This constitutional framework enables the President to control both internal and external security mechanisms, and the police and the army are the two main pillars of presidential power. The President interacts with police services via the Defence Council and through informal networks organised around ethnic affiliation.

\subsection{The Defence Council}

Since the Mobutu era, the President of the Republic was supported by the Conseil National de Sécurité (National Security Council, or GNS). ${ }^{7}$ In practice, the CNS oversaw all security agencies and all national and provincial strategic services. In the new Constitution, the Conseil National de Défense (National Defence Council, or CND) supersedes the GNS. It retains the same mission, constitution and operations as the CNS, and plays a key role at the highest possible level in managing internal security issues and police services.

The Special Advisor on security holds an influential position. He/she can call upon any person to disclose any information for security purposes. $\mathrm{He} / \mathrm{she}$ has complete access to all documents and intelligence. Presently, the Special Advisor, as a member of one of the President's most influential networks, Ngbandi, ${ }^{10}$ exerts considerable power over the security sector.

\subsection{Clans in power}

The President does not rely solely on legally established structures but also on extremely powerful formal and informal networks. These networks overlap and often seek to neutralise each other to protect vested interests. They are notoriously difficult to identify and infiltrate. ${ }^{11}$

The most influential of these networks is l'axe Katangais (the Katangese axis), which is organised around ethnic affiliation. The Katanga network claims to be the rightful successor of the late Laurent Kabila, former President and father of the current President. As was the case during the Mobutu era with the Division Spéciale Présidentielle (Special Presidential Division, or DSP), the Katanga network also has its own armed divisions (such as the Simba battalion, which is controlled by the Inspector General of Police), made up of former soldiers from north Katanga, birthplace of the President. 
The Katanga network is closely linked to southern African interests in the DRC, particularly South African and Zimbabwean networks that have close ties to the mining industry of Katanga and the two Kasaïs). It is also heavily involved in managing the country's police services and therefore in direct competition with the Banyamulenge-Rwandese axis, which is extremely influential within the defence sector. The latter is most influential in the east of the DRC, where it exerts considerable control, particularly in the mining industry, through an illicit mineral extraction network in collusion with armed groups closely linked to the Forces Armées de la RDC (Armed Forces of the DRC, FARDC), and the Rwandan and Tanzanian business sectors. ${ }^{12}$

\subsection{The government}

According to the provisions of the Constitution, the President and the government share the responsibility for security and foreign affairs (Article 91, clause 2). The government is responsible for public administration, the armed forces, the police, and security services. The Prime Minister must keep the President informed of all government activity, including matters of national security. Since Independence, however, the Prime Minister has been less involved in dealing with security issues, which are solely the concern of the President and his close circle.

The government can call upon the Conseil Supérieur de la Police Nationale (Superior National Police Council, or CSPN) to help nominate police generals and high ranking officers. It is made up of the Prime Minister, the Minister of the Interior and Security, the Minister of Justice, the PNC Inspector General and provincial police inspectors. The CSPN, as a consultative body, remains far less influential than the CND, whose Special Advisor has direct links to the presidency and continues to lead on all national security and police matters. ${ }^{13}$

\subsection{The Ministry of the Interior and Security}

The Minister of the Interior and Security, also known as the deputy Prime Minister for the Interior and Security, is responsible for all matters pertaining to home security. ${ }^{14}$ These roles were only created very recently (under Kabila senior), making it difficult for ministers in the position to assert themselves. The Minister's influence depends on his/her personality and personal relationship with the President and his networks, and is often less important than the Special Advisor on security.

Three key police services are nominally accountable to the Minister of the Interior and Security:

- The PNC, headed by an Inspector General

- The DGM

- The ANR.

\subsection{The Inspector General of the PNC}

The Inspector General of the PNC is the most powerful person within the police. The Inspector General is accountable to the Minister of the Interior and Security, but his influence and authority is far greater. The current Inspector General was suspended following accusations of involvement in the murder of Floribert Chebeya, a Congolese human rights activist. He has nevertheless remained very powerful. ${ }^{15}$ His considerable influence stems from his close ties with the President and the Katanga network.

At national level the PNC is made up of the following:

- Police d'Intervention Rapide (rapid intervention police, or PIR) responsible for maintaining order and security;

- Direction des Renseignements Généraux et Services Spéciaux de la Police (Directorate for General Intelligence and Special Police Services, or DRGS), the police's special intelligence division, also known as special services $;^{16}$

- The road traffic police, responsible for road traffic safety and issuing penalty notices;

- The border police, responsible for ensuring security at the country's borders;

- The hygiene and environment police, responsible for environmental protection.

All of these services are deconcentrated at provincial and local levels, via a network of police stations (for territories and towns) or substations (at district level and for groupements).

\subsection{Direction Générale des Migration (General Directorate for Migration, or DGM)}

The DGM is accountable to the Minister of the Interior and Security. The DGM is not part of the PNC but works in collaboration with other security services. The PNC and the DGM often 
cross paths at the borders where they both operate. One major difference between the two is that the DGM is not armed. Like the PNC, the DGM has central and provincial offices, as well as a border police unit.

\subsection{L'Agence Nationale de Renseignements (the National Intelligence Agency, or ANR)}

The ANR falls under the remit of the Minister of the Interior and Security. But in practice ANR agents report directly to the President, which could be explained by the fact that the agency's director is from the Katanga clan.

ANR is responsible for national security, through a number of preventative measures aimed at protecting the stability and sovereignty of the state and its institutions. As a national structure, it covers the entire breadth of the country and is split into central and provincial offices.

In spite of clearly defined duties, the ANR acts like a 'secret service', operating according to its own rules. It is notoriously difficult to gain access to its detention centres. ANR agents often replace regular police officers, criminal investigation officers and justice system representatives. They carry out investigations, make arrests, seize goods, hand out fines and detain people. They also regularly arrest civilians for common law offences, as well as members of the opposition and civil society. ANR is therefore the most criticised of all security services. ${ }^{17}$

\subsection{Officiers et Inspecteurs de Police Judiciaire (Criminal Investigation Officers/Inspectors, or OPJ/IPJ) and the Ministry of Justice}

The Ministry of Justice ${ }^{18}$ is responsible for the socalled police des parquets (police force in charge of prosecutions). In the DRC, a number of different security services, not just the PNC, have a responsibility for prosecution. OPJs and IPJs identify, record and report criminal offences to the Office of Public Prosecutions (Ministère Public). They are referred to as 'the eyes and ears' of the prosecution service as they operate on the ground.

\subsection{Le Comité pour le Suivi de la Réforme de la Police (CSRP) - Police Reform Committee}

In the mid-2000s, the Congolese authorities, together with the support of the international community, mainly the European Union (EU), the UK Department for International Development (DFID), and the United Nations
Organisation Mission in the DRG (MONUG), paved the way for police reform within the overall security sector reform (SSR).

This process started in August 2004 with the seminar on the reform and restructuring of the police in the DRC. Supported by international donors, but officially led by the Ministry of Interior, the Groupe Mixte de Réflexion sur la Réforme et la Réorganisation de la Police (Working Group on Police Reform and Reorganisation, GMRRR or GMR3) was created in November 2005 (GMRRR 2006). Composed of six Congolese members and 16 international members, it was tasked with reflecting upon and formulating proposals on the future of the Congolese police.

The GMRRR produced a status report on the Congolese police highlighting: the militarisation of police services; the devolution of some police powers to ministries other than the ministry of security; the lack of resources; laws and regulations that were not fit-for-purpose; and the lack of a clear mandate for the head of the PNC, who has no real disciplinary powers.

The GMRRR was tasked with drafting an organic law to supersede the 2002 decree on the organisation and operations of the police. The draft defined the new police service as 'a national public service, which is accessible, responsive to the population's needs, civil, professional, unique, apolitical, answerable to civilian authorities, respectful of human rights, and national, regional and international legal instruments'. It included the reorganisation of territorial units in order to 'respond to citizens' needs for peace and tranquillity', and the creation of a police de proximité (community policing, or PdP). The government approved the draft organic law in May 2009. The GMRRR was also tasked with forming the CSRP, which was formerly launched in September 2007.

Headed by the Minister of the Interior and Security, the political arm of the CSRP leads on policy development. It also includes the Ministry of National Defence and Ex-combatants, the Ministry of Justice and Human Rights, the Ministry of Planning, the Ministry of Finance, the Ministry of Budget, the Ministry of Civil Service, the PNC Inspector General, and two civil society representatives. The international community is represented by ambassadors and 
other diplomatic envoys involved in police reform via $a d$ hoc cooperation agreements or formal expressions of intent.

The executive arm is responsible for technical guidance and policy implementation, and is composed of a secretariat and national experts from the PNC, various ministries, civil society, and international experts from the United Nations Organisation Stabilisation Mission in the Democratic Republic of Congo (MONUSCO, formerly MONUC) and the European Union Police. The secretariat was tasked with conceptualising the reform and developing a strategic action plan, with a particular emphasis on implementing the PdP concept.

The PdP concept is based on six key principles, called the three 'Ps' and the three 'Rs' of community policing:

- Proximity, accessibility and availability of public services through the de-concentration of services.

- Partnership and consultation, making full use of the population's social and cultural capital, civil society organisations, traditional leaders and local security councils.

- Prevention and victim support. In particular, it offers outreach services to women and children victims of violence.

- Resolving problems: PdP prioritises the resolution of insecurity issues at local level.

- Accountability (redevabilité) and transparency, including putting mechanisms in place to enable citizens to report cases of police abuse.

- Respect for human rights is at the heart of the PdP's mission.

The action plan for police reform and the PdP approach have become key references for the international community and present a clear path of action for donor engagement. Police practice based on the $\mathrm{PdP}$ concept tends to attract most international funding, to the detriment of the Minister of the Interior and Security. International influence has weakened the CSRP's legitimacy in the eyes of national agencies, with which they should be working collaboratively. ${ }^{19}$ It is therefore ostracised from national decision-making processes and is just another structure within an extremely complex web of agencies. It seems to operate outside national control as a donor-led project, and even the Minister of the Interior and Security has marginalised it. The challenge now lies in securing political buy-in for the CSRP and acceptance of the reform process.

\subsection{The legislature: parliament's role}

The Congolese parliament is made up of two chambers: the lower chamber (National Assembly) and the upper chamber (Senate). A bill must be submitted, examined and validated by the Assembly before being submitted to the Senate for a second reading and adoption. The President then promulgates the new law. Both chambers set up select committees concerned with examining the bills and integrating amendments before final validation by both chambers.

The police reform bill was introduced to, and ratified by, the National Assembly in September 2009, after having been approved by the Interministerial Governmental Commission. Once in the Senate, however, the bill faced a number of stumbling blocks, including:

- Police demilitarisation: this aspect of the bill divided parliamentarians as demilitarisation requires making changes to the Constitution. Revising the Constitution ${ }^{20}$ is a prerequisite for the reform process, but is also very sensitive.

- Police cohesiveness. Articles 2 and 84 of the bill include the merging of existing police services (criminal justice police services, border police, part of the DGM, and Interpol). It did not, however, include the merging of police services with regard to the security of people and property, which was delegated to the armed forces (Article 187 of the constitution). A number of parliamentarians thought it necessary to review these provisions.

- Financial and administrative autonomy: a number of parliamentarians opposed this principle on the basis that the police are not a legal entity and do not have any financial assets. $^{21}$

Because of these issues and the lack of support from the higher echelons of power, the bill has yet to be passed. The majority of parliamentarians are members of l'Alliance pour la Majorité Présidentielle (the Alliance for a Presidential Majority, AMP) made up of le Parti du Peuple pour la Reconstruction et le Développement (the People's Party for Reconstruction and 
Development, PPRD), Parti Lumumbiste (Lumuba Party, PALU), l'Union des Démocrates Mobutistes (Union of Mobutu Democrats, UDEMO), l'Alliance pour la Reconstruction du Congo (the Alliance for the Reconstruction of the Congo, ARC) and other small political parties. They tend to press on with reforms that have been prioritised by the President, and delay those that are thought to be a potential threat to the government's operations. Although the SSR process stipulates that parliament should act as a counter-power, it protects the interests of the executive and the majority of parliamentarians.

In spite of these challenges, senators approved a bill establishing the operations of the PNC on 15 April 2011. ${ }^{22}$ The bill was submitted for review to a special mixed select committee (defence, security, and sociocultural affairs), seconded by a political, administrative and legal committee. It proposes to separate the police force into an administrative branch and a legal branch, working with the judiciary to prosecute offences. It also establishes five police structures: the Superior Council, the General Commissionership, the Inspectorate General, provincial police stations, and territorial and local units.

The CSRP officially welcomed this move as a significant development in the PNC reform process. However, the final document was a watered-down version proposed initially, and is considered by some to be a backward step (N'zeka 2011). The law as it stands does not include decisions agreed by civil society and political leaders on integrating branches, autonomy and organisational structures, including for addressing such issues as genderbased violence (Etinga 2011; N'zeka 2011).

The President must promulgate the law for it to come into force. The most likely scenario is that issues will continue to be debated whilst the reform is being implemented. It will be interesting to see how the new police service will operate without the integration of the police judiciaire des parquets and the police des frontières (border police) within it, and how it will resolve the issues of duplication, which are partly responsible for its current problems. With regard to the financial and administrative autonomy of the police, experts agree that there is an inherent contradiction between the very nature of the police as a public service, and the refusal to treat it as such by granting it the autonomy it requires. One can also question how the police will address important topical issues such as gender-based violence and child protection, which have all been left out of the current law but are central to the police's public service mission.

\subsection{The role of civil society: le Réseau de la Société Civile pour la Réforme du Secteur de Sécurité et Justice (Civil Society Network for the Reform of the Security and Justice Sectors) ${ }^{23}$}

Civil society has been increasingly involved in the reform process since 2006, mostly through the support of the international community. The South African Non-Governmental Organisation (NGO) Institute for Democracy in Africa (IDASA) started working in the DRC, with funding from DFID, with a view to strengthening the involvement of civil society, parliament, the media, and the population in the police reform process. Other aspects of civil society engagement included involvement in drafting the police reform law, monitoring parliamentary activity and supporting the reform's implementation, particularly the PdP.

DFID also supported IDASA and civil society involvement by funding Redevabilité du Secteur de la Sécurité et Réforme de la Police (Security Sector Accountability and Police Reform - SSAPR (SSAPR 2010a, b).

Created in 2006 the Réseau pour la Réforme des Services de Sécurité (Security Services Reform Network, RRSS) managed to bring the issue of security into the public domain, in spite of its organisational weaknesses. The RRSS is considered to be a credible alternative to politicians, and the international community has been supporting it. The RRSS is not the only civil society actor involved in police reform. Despite their organisational weaknesses and fragmentation, the Chebeya case shows that national civil society actors have risked their lives ${ }^{24}$ in support of the reform process.

\section{Local and provincial actors: Bas-Congo case study}

The provincial breakdown of the security sector adds to its complexity. Each province is host to a number of decentralised services and deconcentrated services with vague objectives, which have to collaborate without a clear legal framework. The case study of the organisation of 
the police in the Bas-Congo Province highlights some of these challenges.

The Bas-Congo, the smallest of the DRC's 11 provinces, has existed since 1962. It is one of the richest: thanks to its ideal location it benefits from commercial, economic and agricultural assets. ${ }^{25}$

There are many instances of military interference in civil justice cases, for example land disputes between local communities, immigrant communities and farmers, and customary disputes (between clans). This deficient justice system and insecurity issues are of little concern to the authorities in Kinshasa, who do not supervise the work of their agents in the field. However, they were very concerned with the activities of the former politico-religious movement Bundu dia Kongo (BDK), which contributed to the deterioration of the relationship between the police and the population (see section 5.2 below).

\subsection{Stakeholders involved in the security sector in the Bas-Congo}

The Provincial Governor is the central government representative who coordinates the delivery of deconcentrated public services at provincial level. $\mathrm{He} / \mathrm{she}$ is accountable to central government via the Minister of the Interior and Security (Article 65 of the law on the administration of provinces). The Governor protects national interests, enforces the laws and regulations of the Republic, and maintains security and public order (Article $63, i b i d$.$) . As the chief executive of the province,$ $\mathrm{he} / \mathrm{she}$ is responsible for the administration of all public services.

The Governor of the Bas-Congo Province was elected in January 2007 and governs with the support of ten ministers, including a provincial Minister for Security. In his capacity as representative of the state and the representative of the people of the province, the Governor is both a decentralised and deconcentrated authority. The Governor (a member of the President's party, the PPRD) was elected without having secured the majority of parliamentary seats. It is more than likely that he bought the votes of members of the opposition.

The Provincial Assembly is made up of 29 deputies who elect the Provincial Governor, approve the provincial budget and control the executive. In reality, assembly members lack the experience, academic qualifications, motivation and understanding to address public policy issues. They are more concerned with supplementing their meagre income by engaging in corrupt practices, such as selling their votes to the Governor. ${ }^{26}$ In this context it is difficult to see how they can exercise any control over the provincial government's activities.

The Provincial Minister of the Interior and Security is responsible for maintaining public order, ensuring public safety, protecting people and their property, migration and border surveillance, and immigration control. Provincial ministers must all be natives of the province. The current Minister of the Interior and Security belongs to the presidential majority party. In theory the Governor can delegate the supervision and coordination of security services to the Provincial Minister for Interior and Security, but in reality the position holds very little power. In the Bas-Congo, the Provincial Inspector is far more influential than the Minister as he belongs to a powerful network closely linked to the President.

In Bas-Congo and all other provinces, the Provincial Inspector is responsible for the coordination of deconcentrated police services and accountable to the PNC Inspector General. The Provincial Inspector commands, leads and supervises all provincial police forces as per the laws and regulations of the Republic. This includes the management of human and financial resources, and any buildings and equipment at his disposal. He represents the police force in his dealings with local authorities and other parties.

The Bas-Congo Provincial Inspector has close ties to the General Inspectorate and the President and therefore holds a key position in the management of the province's security services. Although he is answerable to the Provincial Governor, in reality he appears more important. He played a key part in the repression of Bundu Dia Kongo ('the soul of the Congo', BDK) movement (see below), orchestrated by the Minister of the Interior and Security and the PNC General Inspectorate. The law states that the national police force must submit to the local authority under the responsibility of the Ministry of Interior (Article 184 of the Constitution). In practice however, provincial police forces answer 
to their own chain of command rather than the local provincial authority. Despite allocating considerable amounts of money to provincial police services, the local authority does not command the police but can requisition its services.

Field officers work in appalling conditions (unsanitary housing and offices, meagre salaries, dilapidated equipment, lack of decent food, bad health care, etc.) and are often more concerned with ensuring their own survival than complying with regulations and respecting the chain of command. Further, their numbers are inadequate: there are 18 police stations in the Bas-Congo Province, and 126 sub-stations. The police/population ratio is $1 / 2317 . .^{27}$

As the representative of the government at provincial level, the local authority should control all services operating within its administrative area, including the ANR and DGM, which both have local and provincial representations. In practice however, most services answer to their own internal chain of command rather than the local administrative authority.

The Conseil Provincial de Sécurité (the Provincial Security Council, or CPS) is an informal structure that brings together all security and justice agencies and centralises security-related data at provincial level. There is no official document prescribing the organisation of the CPS and the management of the security sector across all of the country's provinces. The CPS appears to be the logical incarnation of the GNS at the provincial level but has no explicit legal mandate. ${ }^{28}$ Decision-makers at province level involved in the security and justice sectors are members of the CPS (PNC, provincial Minister of the Interior and Security, ANR, DGM, FARDC, and judiciary). It is chaired by the Governor, who convenes meetings on an ad hoc basis. In the absence of a clear legal and institutional framework, the Provincial Governor is free to make unilateral decisions without any stakeholder consultation or external scrutiny, leading to poor policy implementation.

Nonetheless, the CSRP believes that the CPS is a valuable and relevant body, which should be revitalised and strengthened. It has therefore been included in the new PdP structure and incorporates civil society representatives.
Various provincial agencies are cascaded down to the local level. The mayor, the bourgmestre, the chef de secteur and chef de chefferie are all local authorities representing both the state and the province in their respective jurisdictions. They are responsible for the smooth running, coordination and supervision of state and provincial services and administrative operations (Article 93 and 94 of the law, Entité Territoriale Décentralisée (Decentralised Territorial Entity, ETD)). The Provincial Governor supervises all ETD activities but can choose to delegate this responsibility to the territorial administrator (Article 95). A number of different local authority leaders have the following responsibilities:

- The mayor is involved in matters pertaining to local security at city level and in doing so can call upon police forces. The mayor must inform the Governor of any significant event taking place in the city and of any dispute or conflict that is likely to threaten public order, which will be escalated to the Minister of the Interior and Security.

- As head of the local council, the bourgmestre is involved in matters pertaining to security at town/village level and can call upon local police services to support the implementation of these duties.

- The chef de secteur or sector chief is involved in matters pertaining to security in a particular secteur.

- The chef de chefferie or chiefdom leader is the local customary leader responsible for the smooth running of his jurisdiction and maintaining public order.

None of these local authority leaders are voted in democratically; neither are they truly autonomous as they retain strong institutional links with central government. For example, the bourgmestres and other local leaders are appointed and dismissed by the central and/or provincial administration.

In some local areas religious and customary leaders play a key role in conflict management and peacekeeping. This is particularly true in rural areas where customary leaders are granted administrative authority and have developed their own security systems and structures, thus further complicating the implementation of new policies and approaches. Villages and other small towns have their own equivalent to the CPS, 
which operates without a clear mandate or legal framework.

\subsection{Security management in the Bas-Congo}

The case study of the Bas-Congo Province highlights the confusion of roles and responsibilities within the police service and the disproportionate use of repressive measures. This casts real doubt over the implementation of the PdP concept, which forms the cornerstone of the reform process backed by the international community.

\subsubsection{An institutional vacuum}

The stakeholder mapping exercise carried out for the purpose of this study does not give an accurate picture of how security services really operate in the DRC. In the Bas-Congo and all other provinces, there is no 'security sector' as such, due to the lack of coordination between services. In the context of a flawed decentralisation process, security services (police, ANR, DGM, FARDG, and military and civilian justice services) at local level operate independently and are often in direct competition with one another. ${ }^{29}$ Security services at provincial level refuse to come under the helm of provincial authorities and remain linked to central government.

Moreover, field agents within the different security agencies are not fully aware of their legal mandate and make up their own rules. Civilians are also mostly unaware of the law and their rights, making them more vulnerable to abuse and easy to control. Most of the security services' funds and equipment come from the provinces, with Kinshasa providing very little support for salaries, equipment and training. Consequently, agents at all levels are engaged in a profitable system of extortion and racketeering at the expense of the Congolese population and with complete impunity (interviews with police officers, 2010, 2011).

Most conflicts between the population and the police are the result of the police's failure to assist those in danger, the usurpation of power, extortions, corruption, arbitrary arrests, illegal detentions, etc. The historical evolution of the police force is partly responsible for this situation. During colonial rule, militia groups were trained to tame, repress and punish those who would not submit to the colonial authorities. In return, the population are fearful and scornful of security agents and the services they represent. Citizens, mostly students, have invented many nicknames for police officers (interviews with students, 2010, 2011).

In this operational vacuum, there is no control over police activities. The Inspector General in Kinshasa does not have the means to carry out inspections or supervise what is happening in the province. Through a system of patronage networks, however, the authorities in Kinshasa are able to exercise a degree of 'control' over the distribution of power and wealth in the province (interviews with police officers and other members of the RRSS, 2010, 2011).

Thus, the authorities in Kinshasa do not intervene in security matters that affect the province unless their political and financial interests are directly at stake. In the Bas-Congo, the authorities collude with business interests in a web of nepotistic networks that control a vast swathe of the province's resources. This discriminatory practice writes many people out of jobs and contributed to the rise of the famous dissident movement Bundu dia Kongo (BDK).

\subsubsection{Repression of the Bundu Dia Kongo movement}

The BDK movement constitutes the biggest organised challenge to the Kinshasa regime in the Bas-Congo. It combines religious and nationalist agendas fuelled by a feeling of marginalisation from central government and provincial authorities (Katende and Bula Bula 2010). Since 2007 BDK have launched a series of strikes and protests in Matadi and other cities, several of which have led to both civilian and police casualties. The police and soldiers have killed 104 people, while about 10 police have been killed. The services involved in this operation of 'restoring public order' are: the President's Office, the Ministry of Home Affairs, the Kinshasa Inspector General, and the Lower Congo Inspector General. This essentially military core, and belonging to the Katanga network, makes up the main players in the management of security issues at the highest level of the state..$^{30}$

After the last, most deadly, episode between the police and the BDK in 2008, relations between the police and the population in the Bas-Congo have deteriorated further. Those who came to maintain public order ended up carrying out hideous massacres which worked to irremediably tarnish the image of security services, whose 
reputation was already poor. In light of this repression of BDK followers - populations in the Lower Congo - find it difficult to trust security services. The catastrophic handling of the BDK episode is illustrative of the dysfunctional nature of different decision-making centres. It was clear from this case that some national and provincial decision-making centres, such as army headquarters and the Provincial Governor, were not well informed about the situation.

\section{Revisiting the PdP concept: an illusion?}

It seems clear that the $\mathrm{PdP}$ concept, promoted by donors through the CSRP, is not a priority for various police divisions. The concept of accountability, one of the basic principles underlying the concept, must be effective in both management processes and also shape the behaviour of police officers. The establishment of a community police force is supposed to be a break away from the old practice of having a militarised police, devoted to the maintenance of governments and the protection of political leaders, and thus aloof from the populations it is supposed to protect.

However, from the discussion above on stakeholders, as well as the Bas-Congo case study, it is clear that the thinking informing such a practice in the DRC is far from being aligned with the interests of actors within the police sector. There is a clear lack of political will from central authorities. Attention to police matters only emerges when the personal safety of powerholders and their different patronage networks is concerned, and never when the security of the population is at stake.

Those at the top of the political establishment resist reform because it might well reduce their 'powers' and ability to loot. The promotion of a 'community police' is inextricably linked with improved pay conditions and would have to go through an audit of police numbers. This would in effect end the use of fictitious employees whose salaries help senior officers supplement their own pay. ${ }^{31}$

Provincial and local authorities, devoid of any real power, are less involved in the implementation process. However, there are a few encouraging initiatives which are worth noting, especially local public discussion groups and exchange fora (SSAPR 2011).
With regard to the national police, expectations of officers are incongruent with what is proposed under the 'community policing' approach. Lower ranked officers welcomed the reform as it was synonymous with improved socio-professional conditions. The approach is summed up in these terms, 'Improve our socio-professional conditions and we will provide better services as you requested in your bill'.

The context for implementation is also difficult, including: a shortage of human resources; poor coverage; difficulties relating to finance; the absence of a coherent legal framework, and the deficient management of resources. Besides, there is also confusion surrounding the PdP concept. Police officers think that it is a new unit, which will be created from scratch. As far as donors are concerned, the community police are not a new unit, but rather a new way of doing things.

One of the main problems associated with the current reform is that it does not take into account other important police units such as the DGM, ANR and the police des parquets (police in charge of criminal investigations).

Civil society, particularly the RRSS, tends to adhere to and promote the PdP concept, mainly under the influence of international actors. The involvement of civil society in matters of security arouses suspicions of political manipulation by international actors: the newly emerging civil society struggles to remain objective and is perceived as suspect by national authorities. Customary authorities question the legitimacy of civil society, and thus pay no heed to its advocacy campaigns.

\section{Conclusion}

Stakeholders of the security and police sectors of the DRC are linked together in a web of complex and dynamic systems, characterised by the discrepancies between theory and practice. These interlocking and multifaceted systems are in constant conflict and fuelled by power relations, tacit agreements and collusions, constraints and opportunism. It is inaccurate to think of these systems and mechanisms as working either in opposition to one another or in parallel; these systems intertwine more than they conflict. It is also worth noting that there are significant overlaps and confusion with regard to the mandates of the existing 
institutions, structures and actors involved. All security services in the DRG possess a legal framework within which they must operate. The legal contradictions and loopholes identified here are often the result of dubious interpretations, or even deliberate misinterpretations of existing operational provisions underlying the functioning of security services.

There is very poor coordination between national and provincial actors, and the various institutions involved. It is important to highlight the shortcomings of a decentralisation process which, when it comes to security services, lacks effectiveness. Indeed, accountability processes in the provinces show the reluctance of local security services to answer to local authorities and their continued dependence on central government. This state of affairs between the two levels of government creates a vacuum which

\section{Notes}

* Based on a paper translated from the French original by Marie-Anne Diedhiou-Roy.

1 Widespread rioting began in Léopoldville stemming from demands for self-government. About 200 Congolese died in the rioting.

2 The 1966 reform splits the PNG into four brigades: intervention, responsible for the security of goods and people; investigation, responsible for criminal investigations; special intelligence; and the road and mobile brigade.

3 The gendarmerie is also organised around specialist brigades each with their own modus operandi: special research and surveillance brigades; road brigade; mobile brigade; air, maritime and fluvial transport brigade; and special child protection brigade.

4 This period was characterised by appalling working conditions for the gendarmerie, leading its agents to engage in frequent racketeering.

5 This body was well equipped with specialist equipment such as truck-mounted water cannons, tear gas, and lethal weapons. It was formed of anti-terrorist, canine and marine units.

6 Informal interviews with stakeholders involved in the police sector, provincial and National Assembly members and the Senate (Commission Politique Administrative et Juridique (Legal Administrative Political Affairs Committee - PAJ) commissions, and defence and security commission).

7 The CNS operates on the basis of four legal is quickly filled by various informal and socioprofessional networks. This creates a dysfunctional structure characterised by a culture of impunity, a semblance of autonomy and independence among actors, but never with regard to senior civil servants in charge of coordination. Thus, issues only emerge when the personal security of the incumbent is threatened, rather than that of the general population.

This is a chaotic system of governance, the survival of which depends on corruption and on the malleability of rules and actors. This intentional fragmentation does not go hand in hand with such concepts as 'coordination and collaboration', or 'community policing' promoted by international partners. The result is the multifaceted provision of security and justice services, characterised by opportunism and open to manipulation and exploitation at the population's expense (RCN 2009).

documents: the Constitution of the Republic of Zaïre, Articles 36 to 45; Decree-law n79-047 dated 6 March 1970 stipulating the organisation and operations of the CNS; Decree-law n ${ }^{\circ} 86$ 036 dated 24 November 1986, revising and modifying the previous decree; and Decree-law n87-032 dated 22 January 1987 stipulating its internal rules and regulations.

8 There are local denominations of the GNS in provinces, towns, cities, territories and districts across the DRC, known as provincial or local security committees.

9 The position of Special Advisor on security has remained the same as during the CNS era.

10 The Special Advisor on security comes from the same Ngbandi ethnic group as Mobutu and also belongs to a very financially powerful group of mixed-raced Congolese, descended from the white colonists. They were very influential during the Mobutu era and quick to re-form under Kabila's son. This politicofinancial network benefits from the considerable support of foreign business sectors, the Europeans and the Americans (World Bank, IMF, etc.)

11 The entire Congolese population knows about the influence of these informal networks, but people hesitate to talk about them openly.

12 There are a number of other influential networks, but they are less present within the military and the police. They include the network of former AFDL members; the Uganda-Ituri and Benyi-Butembo axes, 
involved in mineral and oil extraction; the Angolan axis, a political and military network which controls oil and mineral extraction at the western border of the DRC; the Maniema axis, also a political and military network, made up of generals and politicians that have held or currently hold ministerial positions; and the Bas-Congo axis, centred on the President's wife and her affiliation to the Yombe ethnic group.

13 There is hope that a new law will strengthen the CSPN. Article 22 on the organisation of the police established the CSPN as a consultative body working with the General

Commissionership (commanding and implementing body) and the General Police Inspectorate (control body). The CSPN would develop a code of conduct for the police corps, take part in developing a criminal policy and monitor its implementation within the ministry.

14 This provision refers to Article 184 of the 2006 Constitution, according to which 'the police answer to local authorities, under the overall responsibility of the Ministry of Interior'.

15 The Inspector General controls an antiterrorist battalion called Simba. This battalion is an autonomous unit, almost like a 'police force within the police', made up of forces loyal to the Inspector General. It is better equipped than the police and the army, and is widely feared. It is responsible for the reprisals against the Bundu dia Kongo (BDK) in the Bas-Congo province.

16 Its headquarters used to be in Kin Mazière, in the centre of Kinshasa. These services are currently located within the General Inspectorate, in the town of Lingwala, in front of the Palais du Peuple (People's Palace). The Inspectorate houses a detention centre and the service can arrest and detain civilians for political reasons.

17 Testimonies from Congolese citizens.

18 The Congolese judiciary is organised according to decree-law nº2/020. The 2006 Constitution splits the former Supreme Court into three separate jurisdictional orders (the Constitutional court, the State Council and the Supreme Court of Judicature) and new jurisdictions (work, commerce and administrative tribunals).

19 The EU and the MONUC/MONUSCO are the main agencies involved in this structure, even though other stakeholders are also formally involved from time to time.
20 The state supplies the police with equipment and other infrastructure it needs to operate.

21 We would like to thank A.G.R. Nkata, consultant for the EA-SSAPR, for clarifying this section.

22 Sixty-three voted in favour of the law, none voted against and three abstained.

23 My sincere thanks to the RRSS team and the EA-SSAPR project for including me in the RRSS evaluation and enabling me to collect this information.

24 Many journalists and religious leaders have been killed for speaking up for the rights of the vulnerable (Floribert Chebeya, human rights activist; journalists Franck Gykie from Référence Plus; Papua Muamba from Phare, Kinshasa; Serge Maheshe and Didas Namushimba from Radio Okapi Bikavu, Kinshasa; bishops Muzirwa and Kataliko, Bukavu, and others.).

25 According to DGM statistics, from January to December 2009, 9,213 Congolese were sent back from Angola (5,630 men, 2,966 women, 618 children). Between 6 October and 11 December 2009, 624 Angolans were sent back from the DRG (289 men, 216 women and 119 children) (DRC 2009).

26 In practice, provincial parliamentarians often sell their votes to the most generous buyer, as was the case in Kinshasa and the provinces of Equateur, Occidental and Oriental Kasai.

27 This ratio relates to the city of Matadi and is far from the internationally accepted ratio of one policeman for 300 inhabitants.

28 Based on M. Loochi Kizoungu's working notes. The working notes are based on five legal documents that could partly justify the existence and operations of the CPS. Loochi is a member of RRSS (South Kivu).

29 There are numerous conflicts between the ANR, the PNG and the DGM at the port of Matadi, where many customs transactions take place. Security agents act as protectors or facilitators and charge a fee for their services. This leads to conflicts between agencies, the loss of income for customs services, and the illicit accumulation of wealth of security officials. The government tries to address this by reducing the number of agencies allowed to work at the port, but the excluded agencies never stay away and corruption continues unabated.

30 For more on the Bundu Dia Kongo episode, see the report, We will Crush You by Human Rights Watch (2008). 
31 Besides its relatively small influence on the police, the Minister of the Interior and Security is largely thwarted by presidential services and the Inspector General. Ministry of Interior and Security staff are inexperienced and the Ministry lacks capacity to deal with security

\section{References}

CSRP Working Group (2009) La Police de Proximité en République Démocratique du Congo: Doctrine et Stratégie [Community Policing in the Democratic Republic of Congo: Doctrine and Strategy], Kinshasa

Democratic Republic of Congo (2009) Projet de loi Organique Portant Organisation et Fonctionnement de la Police Nationale Congolaise [Bill on the Establishment of the National Congolese Police], Kinshasa

Democratic Republic of Congo (2006) La Constitution de la République Démocratique du Congo [Constitution of the Democratic Republic of Congo], Kinshasa

Democratic Republic of Congo, Provincial Migration Directorate (2009) Tableau des Refoulés Congolais/Angolais, situation du 06 octobre au 11 décembre 2009 [Number of Angolan and Congolese Nationals turned back at the Border between 06 October and 11 December 2009], BasCongo Province

Ebenga, J. and Nlandu, T. (2005) 'The Congolese National Army: In Search of an Identity', in M. Rupiya (ed.), Evolutions and Revolutions, $A$ Contemporary Africa, Pretoria: South Africa: Institute for Security Studies

Etinga, S. (2011) 'Le Sénat adopte la Loi sur le Fonctionnement de la Police Nationale' ['The Senate adopts Law on the Operations of the PNC'], Le Potential, 16 April, www.lepotentiel.cd/ 2011/04/le-senat-adopte-la-loi-sur-lefonctionnement-de-la-police-nationale.html (accessed 5 October 2011)

GMRRR (2006) GMRRR Final Report, Kinshasa: Groupe Mixte de Réflexion sur la Réforme et la Réorganisation de la Police, www.reformedelapnc.org/documents/GMRRR _Report-en-Francais-2006.pdf; www.reformedelapnc.org (both accessed 5 October 2011)

Human Rights Watch (2008) On va vous Écraser, la Restriction de l'espace Politique en République Démocratique du Congo [We will Crush You, the Restriction of Political Space in the Democratic Republic of Congo], Human Rights Watch, www.hrw.org/en/node/76188/section/7, November (accessed 18 November 2011) matters in-country. The changes brought about by the reform of the police, and particularly the introduction of community policing, require a strong political and strategic vision, as well as institutional restructuring and changes in dayto-day work processes.

Katende, J.C. and Bula Bula, R. (2010) Rapport 50 ans de la VSV... Tous les Gouvernements ont les mains Couvertes de Sang [50 Years of the VSV... All Governments have got Blood on their Hands], Rapport de l'Association Africaine de Défense des Droits de l'Homme en R.D.Congo (ASADHO), Kinshasa

N'zeka, L. (2011) 'Plaidoyer pour l'insertion des Options Fondamentales de la Réforme de la Police Nationale' ['Advocacy for the Integration of Fundamental Options in the Reform of the National Police Service'], in Groupe l'Avenir, 25 March, Kinshasa, www.groupelavenir.cd/spip.php?article39167 (accessed 5 October 2011)

RGN (2009) La Justice de Proximité au Bas-Congo [Community Justice in the Bas-Congo], study commissioned by the Japanese International Cooperation Agency (JICA), RGN Justice et Démocratie

SSAPR (2011) Rapport Travaux d'Élaboration de Stratégie Police de Proximité [Report on the Development of the Community Policing Strategy], Kinshasa: Security Sector Accountability and Police Reform

SSAPR (2010a) 'Composante Redevabilité Externe Programme d'appui à la Redevabilité du Secteur de Sécurité et la Réforme de la Police en République Démocratique du Congo' ['External Accountability Component of the Security Sector Accountability Programme and Police Reform in the Democratic Republic of Congo'], Training Module for the Justice Sector, DAI, under the leadership of Thierry Nlandu, Kinshasa: Security Sector Accountability and Police Reform

SSAPR (2010b) Les Systèmes Locaux de Sécurité et de Justice en République Démocratique du Congo. Etude de cas dans les Provinces du Bas-Congo, du Kasaï Occidental et du Sud-Kivu [Local Security and Justice Systems in the Democratic Republic of Congo. Case Study of the Bas-Congo, Occidental Kasai and South-Kivu Provinces], Kinshasa: Security Sector Accountability and Police Reform, External Accountability RGN 